\title{
PUTUSAN LEPAS DALAM KASUS TINDAK PIDANA KORUPSI DI TINJAU DARI UU NO. 31 /1999 JO. UU NO. 20 TAHUN 2001 TENTANG PEMBERANTASAN KORUPSI (Studi Perkara No. 942/ Pid. B/2005/PN.Smg Jo.Putusan Kasasi No.898 K/Pid.Sus /2008)
}

\author{
Nada Fitri Satyawan, Rochmani \\ Fakultas Hukum, Universitas Stikubank (UNISBANK) Semarang \\ Email: Nadasatyawan1@gmail.com, Rochmani@edu.unisbank.ac.id
}

\begin{abstract}
ABSTRAK
Dalam pasal 67 KUHAP disebutkan bahwa terdakwa atau penuntut umum berhak untuk meminta banding terhadap putusan pengadilan tingkat pertama kecuali putusan bebas, lepas dari segala tuntutan hukum yang menyangkut masalah kurang tepatnya penerapan hukum dan putusan pengadilan dalam acara cepat. Dengan demikian terhadap putusan lepas tidak dapat diajukan banding, namun demikian faktanya ada jaksa yang mengajukan banding terhadap putusan lepas sebagaimana ada dalam akta banding nomor: 60/Banding/akta.Pid/2006/PN.Smg dalam perkara tindak pidana korupsi. Adapun yang menjadi permasalahan dalam penelitian ini adalah: (1) Bagaimana putusan lepas dari tuntutan hukum ditinjau dari Undang - Undang No. 31 /1999 jo. Undang - undang no. 20 tahun 2001 (studi perkara No. 942/Pid.B/2005/PN.Smg)? (2) Apakah terhadap putusan lepas dari tuntutan hukum berdasar perkara No. 942/ Pid. B/2005/PN.Smg Jo.Putusan Kasasi No.898 K/Pid.Sus /2008 dapat dilakukan upaya hukum?. Tipe penelitian yang digunakan dalam penelitian ini adalah tipe penelitian hukum normatif pada peristiwa hukum tertentu. Penerapan tesebut dapat diwujudkan melalui perbuatan nyata dan dokumen hukum, hasil penerapan akan menciptakan pemahaman realisasi pelaksanaan ketentuan - ketentuan hukum normatif yang dikaji telah dijalankan secara patut atau tidak. Berdasarkan hasil penelitian dan pembahasan adalah Putusan lepas berdasarkan perkara No. 942/ Pid. b/2005/PN.Smg yang menggunakan Undang - Undang No. 31 /1999 jo. uu no. 20 tahun 2001 sebagai dasar pemidanaan, didalam proses peradilannya ternyata unsur - unsur pasal yang didakwakan oleh Jaksa Penuntut Umum dinyatakan terbukti, namun karena perbuatan dari Terdakwa I dan Terdakwa II tersebut dilakukan atas perintah atasan maka berdasarkan pasal 51 ayat 1 KUHP, sehingga perbuatan terdakwa I dan Terdakwa II tersebut tidak dapat dipertanggung jawabkan oleh Terdakwa I dan Terdakwa II karena merupakan perbuatan untuk melaksanakan perintah jabatan yang diberikan oleh atasannya yaitu Walikota Semarang dan diputus Lepas dari tuntutan hukum. Terhadap putusan lepas berdasarkan Putusan Pengadilan Negeri No. 942/ Pid. B/2005/PN.Smg Jo.Putusan Kasasi No.898 K/Pid.Sus /2008 yang memutuskan untuk Terdakwa I dan II lepas dari segala tuntutan hukum, maka berdasarkan pasal 67 KUHAP putusan lepas dari segala tuntutan hukum hanya bisa dilakukan upaya hukum melalui kasasi.
\end{abstract}

Kata Kunci : Korupsi, Upaya Hukum, Putusan Lepas. 


\begin{abstract}
Article 67 of the Criminal Procedure Code states that defendants or public prosecutors have the right to appeal against decisions of the first level court except for acquittals, apart from all lawsuits concerning the problem of inaccurate application of the law and court decisions in rapid proceedings. Therefore, an appeal against a decision cannot be appealed, however, the fact is that there are prosecutors who appealed against the verdict as contained in the appeal deed number: 60 / Appeal / deed.Pid / 2006 / PN. As for the problems in this research are: (1) How can the decision to be released from lawsuits in terms of Law No. 31/1999 jo. Law no. 20 of 2001 (case study No. 942 / Pid.B / 2005 / PN.Smg)? (2) Whether the decision is free from legal charges based on case No. 942 / Pid. B / 2005 / PN.Smg Jo. Cassation Decision No.898 K / Pid.Sus / 2008 can legal remedies be made? The type of research used in this research is the type of normative legal research on certain legal events. The application can be realized through concrete actions and legal documents, the results of the application will create an understanding of the realization of the implementation of the normative legal provisions that have been studied properly or not. Based on the results of research and discussion is a decision based on case No. 942 / Pid. b / 2005 / PN.Smg which uses Law No. 31/1999 jo. UU no. 20 of 2001 as a basis for conviction, in the judicial process it turned out that the elements of the articles charged by the Public Prosecutor were proven proven, but because the actions of Defendant I and Defendant II were carried out at the orders of their superiors, based on article 51 paragraph 1 of the Criminal Code, so that the actions of Defendant I and Defendant II cannot be held accountable by Defendant I and Defendant II because it is an act to carry out a position order given by his superior, namely the Mayor of Semarang and was decided to be released from the lawsuit. Against the decision to release based on the District Court Decision No. 942 / Pid. B / 2005 / PN.Smg Jo. Cassation Decision No.898 K / Pid.Sus / 2008 which decided that Defendants I and II were to be freed from all legal charges, so based on article 67 of the Criminal Procedure Code a decision to release all lawsuits could only be legal remedies through cassation.
\end{abstract}

Keywords : Corruption, Legal Efforts, Release Decision. 


\section{PENDAHULUAN}

Penegakan hukum tindak pidana korupsi di Indonesia memang sedang menjadi sorotan, terlebih lagi dengan berkembangnya sistem teknologi informasi dimana masyarakat bisa secara cepat memberitakan bahkan menyebarluaskan melalui media sosial ataupun portal berita elektronik didunia maya. Belum lama ini Bupati Purbalingga terjerat operasi tangkap tangan (OTT) oleh Komisi Pemberantasan Korupsi ${ }^{1}$ adalah salah satu contoh gencarnya agenda pemberantasan korupsi dan cepatnya pemberitaan sekarang ini.

Pemerintahan Jokowi melalui Nawacita yang merupakan bagian dari visi dan misinya mempunyai tantangan yang cukup besar untuk melakukan pemberantasan korupsi ${ }^{2}$ karena selain harus membongkar korupsi yang sudah menggurita juga harus memastikan peraturan perundangan yang menjadi dasar pemberantasan korupsi ditetapkan dengan subtansi yang tegas dan tidak bertentangan dengan norma hukum yang ada.

Berbicara tentang penegakan hukum secara umum akan berbicara juga tentang sistem peradilan pidana, Mardjono Reksodipoetra memberikan batasan terhadap sistem peradilan pidana sebagai sistem pengendalian kejahatan yang terdiri dari lembaga-lembaga Kepolisian,

https://m.antaranews.com/berita/716260/kpk -jelaskan-kronologi-ott-bupati-purbalingga, diakses tanggal 7 Juni 2018, pukul 09.40.

2 strategi nomor 4 yaitu menolak Negara lemah dengan melakukan reformasi sistem, dan penegakan hukum yang bebas korupsi, bermartabat dan terpercaya
Kejaksaan, Pengadilan dan Pemasyaratan terpidana ${ }^{3}$. Disisi lain dalam perkembangannya sebagaimana diatur dalam Pasal 5 Undang-undang nomor 18 tahun 2003 tentang Advokat, menyatakan bahwa Penasihat Hukum adalah penegak hukum, sehingga dengan demikian penasihat hukum adalah bagian dari subsistem peradilan pidana. Rangkaian penyelesaian kasus dalam acara pidana termasuk tindak pidana korupsi adalah melakukan penyelidikan, penyidikan dan penuntutan terhadap tindak pidana ataupun tindak pidana korupsi, selain itu yang tidak kalah pentingnya adalah keberadaan lembaga peradilan, dari proses pemidanaan hakim adalah penentu, apakah terdakwa akan menjadi terpidana yang konsekuensinya akan bersinggungan dengan Lembaga Pemasyarakatan, atau bahkan akan divonis bebas dan/atau lepas. Lembaga atau institusi penegak hukum sebagai bagian dari sistem peradilan pidana harus mampu melaksanakan kewajiban dan tanggung jawabnya sesuai dengan peraturan perundangan yang berlaku, meski demikian rekomendasi atau putusan yang dikeluarkan lembaga penegak hukum tersebut belum tentu memenuhi rasa keadilan masyarakat.

Pada kasus yang penulis angkat dalam skripsi ini, penulis akan menyampaikan fakta upaya hukum yang dilakukan Jaksa Penuntut Umum sebagai bagian dari penegak hukum dalam sistem peradilan pidana, atas putusan lepas Drs.

${ }^{3}$ M.Faal, Penyaringan Perkara Pidana oleh Polisi (Diskresi Kepolisian), Pradnya Paramita, Jakarta, 1991, Hlm.24. 
Sujoko (terdakwa I), Drs. Heru Supriyono, M.Pd (terdakwa II). Sementara disebutkan dalam Pasal 67 KUHAP disebutkan bahwa terdakwa atau penuntut umum berhak untuk meminta banding terhadap putusan pengadilan tingkat pertama kecuali terhadap putusan bebas, lepas dari segala tuntutan hukum yang menyangkut masalah kurang tepatnya penerapan hukum dan putusan pengadilan dalam acara cepat. Hal ini menarik untuk dikaji untuk melihat apa makna dari putusan lepas dari tuntutan hukum

\section{METODE PENELITIAN}

\section{Tipe penelitian}

Berdasarkan rumusan masalah dan tujuan penelitian, maka tipe pendekatan yang digunakan adalah tipe penelitian yuridis normatif, yaitu penelitian yang difokuskan untuk mengkaji penerapan kaidah-kaidah atau norma-norma dalam hukum positif. ${ }^{4}$ Yuridis Normatif, yaitu pendekatan yang menggunakan konsepsi legis positivis. Konsep ini memandang hukum identik dengan norma-norma tertulis yang dibuat dan diundangkan oleh lembaga atau pejabat yang berwenang. Konsepsi ini memandang hukum sebagai suatu sistem normatif yang bersifat mandiri, tertutup dan terlepas dari kehidupan masyarakat yang nyata. ${ }^{5}$ Hasil penerapan akan menciptakan pemahaman realisasi pelaksanaan ketentuan - ketentuan hukum normatif yang dikaji telah dijalankan

4 Johnny Ibrahim, 2006, Teori dan Metodologi Penelitian Hukum Normatif, Malang: Bayumedia Publishing, hlm. 295.

5 Ronny Hanitijo Soemitro, 1988, Metodologi Penelitian Hukum dan Jurimetri, Jakarta: Ghalia Indonesia, hlm. 13-14. serta sejauh mana penerapan Pasal 67 KUHAP oleh Jaksa Penuntut Umum dalam memaknai putusan lepas dari tuntutan hukum tersebut.

Berdasarkan hal diatas maka penulis tertarik untuk melakukan penelitian dalam rangka penulisan skripsi, "Putusan Lepas Dalam Kasus Tindak Pidana Korupsi Di Tinjau Dari UU No. 31 /1999 Jo. UU No. 20 Tahun 2001 Tentang Pemberantasan Korupsi (Studi Perkara No. 942/ Pid. B/2005/Pn.Smg Jo.Putusan Kasasi No.898 K/Pid.Sus /2008)."

secara patut atau tidak. Hal ini untuk memperoleh pengetahuan tentang bagaimana proses pelaksanaan Putusan Perkara No. 942/Pid.B/2005/PN.SMG Jo.Putusan Kasasi No.898 K/Pid.Sus /2008.

\section{Spesifikasi Penelitian}

Spesifikasi yang penulis gunakan adalah deskriptif analisis yaitu analisis penelitian yang bertujuan menggambarkan kenyataan yang ada di obyek penelitian. Selain itu juga bertujuan melakukan pembahasan terhadap kenyataan dibanding dengan kajian kepustakaan.

\section{HASIL PENELITIAN DAN}

\section{ANALISIS DATA}

1. Putusan perkara Nomor 942/Pid.B/2005/PN.Smg untuk Terdakwa I dan Terdakwa II Drs. Heru Supriyono, M.Pd.

Dalam perkara Drs. Heru Supriyono, MPd., pada putusan Nomor: 942 / Pid. B/ 2005/ PN. Smg telah diputus lepas dari segala tuntutan adapun putusannya adalah sebagai berikut:

1. Menyatakan Terdakwa I. Drs. 
Sujoko Bin Isno Notoprawiro dan Terdakwa II. Drs. Heru Supriyono, Mpd tidak terbukti secara sah dan meyakinkan bersalah melakukan tindak Pidana sebagaimana didakwaan pada dakwaan PRIMAIR;

2. Membebaskan Terdakwa I. Drs. Sujoko Bin Isno Notoprawiro dan Terdakwa II. Drs. Heru Supriyono, Mpd oleh karena itu dari dakwaan Primair;

3. Menyatakan Terdakwa I. Drs. Sujoko Bin Isno Notoprawiro dan Terdakwa II. Drs. Heru Supriyono, Mpd terbukti melakukan perbuatan yang didakwakan kepadanya sebagaimana dalam dakwaan SUBSIDAIR, tetapi perbuatan tersebut dilakukan atas perintah atasan;

4. Menyatakan Terdakwa I. Drs. Sujoko Bin Isno Notoprawiro dan Terdakwa II. Drs. Heru Supriyono, Mpd dilepas dari segala tuntutan hukum;

5. Memulihkan hak Terdakwa I dan Terdakwa II dalam kemampuan, Kedudukan dan harkat serta martabatnya;

6. Membebankan Biaya Perkara untuk Terdakwa I dan Terdakwa II kepada Negara; 6 Atas Putusan Lepas Tersebut Jaksa Penuntut Umum Pengadilan Negeri Semarang Melakukan 2 (dua) Upaya Hukum yakni Banding dan Kasasi.

${ }^{6}$ Salinan Putusan Pengadilan Negeri Semarang No.942/ Pid.B/2005/PN.Smg.

\section{Putusan Banding Pengadilan Tinggi Jawa Tengah No.302/Pid/2006/PT.Smg}

$\begin{array}{ccr}\text { Adapun } & \text { putusan } & \begin{array}{r}\text { Pengadilan } \\ \text { Tinggi }\end{array} \\ \text { Jawa } & \text { tengah }\end{array}$ No.302/Pid/2006/PT.Smg atas upaya banding yang diajukan oleh Jaksa Penuntut Umum adalah:

Mengadili

1. Menerima permintaan Banding dari Jaksa Penuntut Umum dan dari Terdakwa III serta Terdakwa IV;

2. Membatalkan putusan pengadilan Negeri Semarang Tanggal 15 Agustus 2006 Nomor: 942/Pid.B/2005/PN. Smg. Yang dimintakan banding tersebut;

Mengadili Sendiri

1. Menyatakan Terdakwa I. Drs. Sujoko Bin Isno Notoprawiro dan Terdakwa II. Drs. Heru Supriyono, Mpd tidak terbukti secara sah dan meyakinkan bersalah melakukan tindak pidana sebagaimana didakwakan pada dakwaan;

2. Membebaskan Terdakwa I. Drs. Sujoko Bin Isno Notoprawiro dan Terdakwa II. Drs. Heru Supriyono, Mpdoleh karena itu dari dakwaan primair;

3. Menyatakan I. Drs. Sujoko Bin Isno Notoprawiro dan Terdakwa II. Drs. Heru Supriyono, Mpd terbukti secara sah dan meyakinkan bersalah melakukan tindak pidana yang didakwakan kepadanya dalam dakwaan SUBSIDAIR. Yakni bersama - sama melakukan Korupsi secara berlanjut; 
Selain dinyatakan bersalah Drs. Heru Supriyono, Mpd dijatuhi Pidana penjara selama 1 (satu) Tahun dan membayar denda sebesar Rp. 50.000.000,(Lima Puluh Juta Rupiah). ${ }^{7}$

\section{Kasasi yang diajukan Jaksa Penuntut Umum dan Terdakwa}

Adapun alasan - alasan Jaksa Penuntut Umum dan terdakwa mengajukan kasasi adalah sebagai berikut:

1. Alasan Kasasi Jaksa Penuntut Umum "Bahwa alasan alasan kasasi jaksa penuntut umum tidak dibenarkan, karena judex facti tidak salah dalam menerapkan hukum, dan berat ringannya pidana adalah wewenang judex facti";

2. Alasan Kasasi Terdakwa "Bahwa alasan alasan kasasi terdakwa tidak dapat dibenarkan, karena judex facti tidak salah menerapkan hukum, lagi pula keberatan tersebut mengenai penilaian hasil pembuktian yang bersifat penghargaan tentang suatu kenyataan, keberatan semacam itu tidak tidak dapat dipertimbangkan dalam pemeriksaan dalam tingkat kasasi, karena pemeriksaan dalam tingkat kasasi hanya berkenaan dengan tidak diterapkan suatu peraturan hukum atau peraturan hukum tidak diterapkan sebagaimana mestinya, atau apakah cara

${ }^{7}$ Salinan Putusan Pengadilan Tinggi Jawa tengah No. 302/Pid/2006/PT. Smg mengadili tidak dilaksanakan menurut ketentuan Undang Undang, dan apakah Pengadilan telah melampaui batas wewenangnya, sebagaimana yang dimaksud dalam pasal 253 Kitab Undang - Undang Hukum Acara Pidana (Undang - Undang No. 8 Tahun 1981).

Atas alasan - alasan kasasi yang disampaikan oleh Jaksa Penuntut Umum tersebut diatas melahirkan putusan dari mahkamah agung No.898 K/Pid. Sus/ 2008 yang dalam amar putusannya adalah sebagai berikut:

\section{Mengadili}

Menolak permohonan kasasi dari pemohon kasasi : Jaksa/Penuntut Umum pada Kejaksaan Negeri Semarang dan para Terdakwa tersebut;

Membebankan para pemohon tingkat Kasasi/ Para Terdakwa tersebut untuk membayar biaya perkara dalam tingkat kasasi ini sebesar Rp. 2.500,- (Dua Ribu Lima Ratus Rupiah). ${ }^{8}$

Atas Putusan kasasi Mahkamah Agung tersebut Jaksa Penuntut Umum (JPU) Kejaksaan Negeri Semarang menafsirkan putusan Kasasi nomor 898 K/Pid.Sus/2008 secara berbeda sehingga Terdakwa mengajukan permohonan peninjauan kembali dan Majelis Hakim Agung Peninjauan Kembali menetapkan keputusannya melalui putusan Mahkamah Agung No.

\footnotetext{
${ }^{8}$ Salinan Putusan Kasasi Mahkamah Agung No.898 K/Pid. Sus/ 2008
} 
70PK/Pid.Sus/2011 tanggal 28 April 2011, yang amar putusannya menolak permohonan pemohon dan permohonan yang dimohonkan tetap berlaku.

\section{Putusan lepas dari tuntutan hukum ditinjau dari Undang - Undang No. 31 /1999 jo. Undang - undang no. 20 tahun 2001 (studi perkara nomor 942/Pid.B/2005/PN.Smg).}

Dalam perkara Nomor 942/Pid.B/2005/PN.Smg terdapat 4 (empat) terdakwa yaitu :

1. Terdakwa I : Drs. Sujoko dalam jabatannya sebagai Kepala Dinas Pendidikan Kota Semarang;

2. terdakwa II : Drs. heru Supriyono, Mpd. dalam jabatannya sebagai wakil Kepala Dinas Pendidikan Kota Semarang;

3. Terdakwa III : Yulius Basiwantoro, BA dalam jabatannya sebagai anggota DPRD Kota Semarang dan Wakil sekertaris DPC PDI-P Kota Semarang;

4. Terdakwa IV : Untung Sudjarno, SH. dalam jabatannya sebagai wakil Bendahara DPC PDI-P Kota Semarang.

Putusan Pengadilan Negeri Semarang Nomor 942/Pid.B/2005/PN.Smg tanggal 15 Agustus 2006 khusus untuk Terdakwa I dan Terdakwa II dalam dakwaan Jaksa penuntut Umum Pengadilan Negeri Semarang di dakwa dengan dakwaan subsidair dengan dakwaan primair Pasal 2 jo. Pasal 18 UU No. 31 Tahun 1999 tentang Pemberantasan Tindak
Pidana Korupsi yang telah dirubah dengan UU No. 20 Tahun 2001 tentang Perubahan Atas UndangUndang Nomor 31 Tahun 1999 Tentang Pemberantasan Tindak Pidana Korupsi Jo. Pasal 55 Ayat (1) ke-1 KUHP Jo. Pasal 64 ayat (1) KUHP dan subsidair Pasal 3 jo. Pasal 18 UU No. 31 Tahun 1999 tentang Pemberantasan Tindak Pidana Korupsi yang telah dirubah dengan UU No. 20 Tahun 2001 tentang Perubahan Atas Undang-Undang Nomor 31 Tahun 1999 Tentang Pemberantasan Tindak Pidana Korupsi Jo. Pasal 55 Ayat (1) ke-1 KUHP Jo. Pasal 64 ayat (1) KUHP, Adapun bunyi pasal-pasal yang didakwakan adalah sebagai berikut :

Untuk mengawali paparan analisis, penulis coba akan menjelaskan secara runtut dakwaan jaksa dalam fakta persidangan dibuktikan yang menjadikan hakim memutuskan untuk Terdakwa I dan Terdakwa II dalam perkara Nomor 942/Pid.B/2005/PN.Smg diputus lepas dari segala tuntutan hukum.

Upaya hukum terhadap putusan lepas dari tuntutan hukum berdasar perkara No. 942/Pid. B/2005/PN.Smg Jo. Putusan Kasasi No.898 K/Pid.Sus /2008.

Secara eksplisit didalam KUHAP tidak ada satu pasal pun yang menyebutkan bahwa upaya hukum atas putusan lepas (onslag van recht vervolging) adalah kasasi namun dari beberapa pasal didalam KUHAP bisa ditemukan bahwa secara tersirat putusan lepas dari segala tuntutan hukum bisa dilakukan upaya kasasi hal ini bisa 
kita lihat dalam pasal - pasal yang terdapat dalam KUHAP berikut ini ${ }^{9}$ :

a) Pasal 67 KUHAP "Terdakwa atau penuntut umum berhak untuk minta banding terhadap putusan pengadilan tingkat pertama kecuali terhadap putusan bebas, lepas dari segala tuntutan hukum yang menyangkut masalah kurang tepatnya penerapan hukum dan putusan pengadilan dalam acara cepat."

b) Pasal 233 ayat (1) "Permintaan banding sebagaimana dimaksud dalam Pasal 67 dapat diajukan ke pengadilan tinggi oleh terdakwa atau yang khusus dikuasakan untuk itu atau penuntut umum."

c) Pasal 233 ayat (2) "Hanya permintaan banding sebagaimana dimaksud dalam ayat (1) boleh diterima oleh panitera pengadilan negeri dalam waktu tujuh hari sesudah putusan dijatuhkan atau setelah putusan diberitahukan kepada terdakwa yang tidak hadir sebagaimana dimaksud dalam Pasal 196 ayat (2)."

d) Pasal 244 KUHAP yang berbunyi "terhadap putusan perkara pidana yang diberikan pada tingkat terakhir oleh pengadilan lain selain dari Mahkamah Agung, terdakwa atau penuntut umum dapat mengajukan pemeriksaan kasasi ke Mahkamah Agung, kecuali terhadap putusan bebas". e) Pasal 245 ayat (1) KUHAP yang berbunyi "Permohonan kasasi disampaikan oleh pemohon kepada panitera pengadilan yang telah memutus perkaranya dalam tingkat pertama, dalam waktu empat belas hari sesudah putusan pengadilan yang dimintakan kasasi itu diberitahukan kepada terdakwa"

Terkait dengan perkara Nomor: 942/ Pid. B/2005/PN.Smg Jo. Putusan Kasasi Nomor: 898 K/Pid.Sus /2008 untuk terdakwa Drs. Heru Supriyono, M.Pd Jaksa Penuntut Umum Kejaksaan Negeri Semarang telah melakukan malpraktik yakni telah melakukan 2 (dua) Upaya Hukum banding dan kasasi atas putusan pengadilan Negeri Semarang Nomor 942/Pid.B/2005/PN.Smg yang diputus onslag van recht vervolging adalah salah satu bentuk malpraktik yang dilakukan JPU yang bertentangan dengan pasal 67 KUHAP. "Terdakwa atau penuntut umum berhak untuk minta banding terhadap putusan pengadilan tingkat pertama kecuali terhadap putusan bebas, lepas dari segala tuntutan hukum yang menyangkut masalah kurang tepatnya penerapan hukum dan putusan pengadilan dalam acara cepat."

\section{Simpulan}

Berdasarkan hasil penelitian dan pembahasan mengenai putusan lepas dalam kasus tindak pidana korupsi di tinjau dari uu no. 31 /1999 jo. uu no. 20 tahun 2001 tentang pemberantasan korupsi (studi perkara no. 942/ Pid. b/2005/pn.smg

\footnotetext{
${ }^{9}$ KUHAP
} 
jo.putusan kasasi no.898 k/pid.sus 12008) dapat disimpulkan :

Putusan lepas berdasarkan perkara No. 942/ Pid. b/2005/PN.Smg yang menggunakan Undang - Undang No. 31 /1999 jo. uu no. 20 tahun 2001 sebagai dasar pemidanaan, didalam proses peradilannya ternyata unsur - unsur pasal yang didakwakan oleh Jaksa Penuntut Umum dinyatakan terbukti, namun karena perbuatan dari Terdakwa I dan Terdakwa II tersebut dilakukan atas perintah atasan maka berdasarkan pasal 51 ayat 1 KUHP, sehingga perbuatan terdakwa I dan Terdakwa II tersebut tidak dapat dipertanggung jawabkan oleh Terdakwa I dan Terdakwa II karena merupakan perbuatan untuk melaksanakan perintah jabatan yang diberikan oleh atasannya yaitu Walikota Semarang dan diputus Lepas dari tuntutan hukum.

Terhadap putusan lepas berdasarkan Putusan Pengadilan Negeri No. 942/ Pid. B/2005/PN.Smg Jo.Putusan Kasasi No.898 K/Pid.Sus /2008 berdasarkan pasal 67 KUHAP putusan lepas dari segala tuntutan hukum hanya bisa dilakukan upaya hukum melalui kasasi.

\section{Saran}

Bagi para penegak hukum atau mereka yang merupakan bagian dari sistem peradilan pidana termasuk didalamnya panitera, dalam menjalankan tugas dan kewenangannya harus tetap berpegang pada peraturan perundangan yang berlaku, sehingga tercipta sistem yang jujur, adil dan tidak memihak;
Perlu adanya kajian tentang proses putusan pengadilan pidana yang terbukti merupakan proses peradilan sesat atau putusan peradilan yang terbukti merupakan bagian dari mafia peradilan perlu dimasukkan pada katagori pelanggaran ham berat karena berkaitan dengan perampasan kemerdekaan seseorang yang dilakukan secara sistemik, dengan mekanisme peradilan yang berbeda seperti disebutkan pada Undangundang Hak Asasi Manusia, dimana putusannya bisa menganulir putusan yang dianggap melanggar Ham tersebut; atau

Memaksimalkan peran dan kewenangan, Ombudsman, Komisi Kepolisian, Komisi Kejaksaan serta Komisi Yudisial ketika terdapat penegak hukum dalam melaksanakan tugas dan kewajibannya melampaui kewenangannya bahkan melanggar peraturan perundangan, keputusan atau rekomendasinya merupakan keputusan yang bisa memberikan efek jera terhadap pelakunya dalam perspektif keadilan korban.

\section{Daftar pustaka}

\section{Literatur}

M.Faal, 1991. Penyaringan Perkara Pidana oleh Polisi (Diskresi Kepolisian). Jakarta: Pradnya Paramita.

Arief, Barda Nawawie. 2007. Masalah Penegakan Hukum dan Kebijakan Hukum Pidana Dalam Penanggulangan Kejahatan, Jakarta:Kencana. Atmasasmita, Romli. 2010. Sistem Peradilan Pidana

Kontemporer. Jakarta: Kencana Predana Media Group.

Haditomo,Aswanto. 2008.Tindakan 
Hukum Terhadap Pela- ku Tindak Pidana Korupsi. Jakarta: Dara Wacana Press.

Ibrahim, Johnny. 2006, Teori dan Metodologi Penelitian Hukum Normatif. Malang: Bayumedia Publishing.

\section{Jurnal}

Jurnal Hukum Khaira Ummah Vol.

13. No. 1 Maret 2018

Jurnal Ilmu Hukum, Volume 7 NO.

1, Agustus 2017-Januari 2018

\section{Perundang - undangan}

Kitab undang - undang hukum acara pidana

Salinan Putusan Pengadilan Negeri Semarang No.942/ Pid.B/2005/PN.Smg. Salinan Putusan Pengadilan Tinggi Jawa tengah No. 302/Pid/2006/PT. Smg.

Salinan Putusan Kasasi Mahkamah Agung No.898 K/Pid. Sus/ 2008.

\section{Website}

https://m.antaranews.com/berita/716 260/kpk-jelaskan-kronologiott-bupati-purbalingga
Soemitro,Ronny Hanitijo.1988. Metodologi Penelitian Hukum dan Jurimetri, Jakarta: Ghalia Indonesia. 